Agro-Science Journal of Tropical Agriculture, Food, Environment and Extension Volume 19 Number 4 (October 2020) pp. 51 - 55

ISSN 1119-7455

\title{
EFFECTS OF WOOD HARVESTING ON THE LIVELIHOOD OF FOREST FRINGE COMMUNITIES IN SOUTHWEST NIGERIA
}

\author{
*Awe F., Olarewaju T.O., Orumwense L.A. and Olatunji B.T. \\ Forest Economics \& Extension Department, Forestry Research Institute of Nigeria, \\ P.M.B. 5054, Jericho Hills, Ibadan, Oyo State, Nigeria \\ *Corresponding author's email: femray4real@yahoo.com
}

\begin{abstract}
This study was carried out to assess effects of wood harvesting on the livelihood of forest communities in Ibarapa region, southwest, Nigeria. The study was conducted to identify the various livelihood activities engaged in by forest communities in the region; to assess how wood harvesting in the forests has affected the livelihood of the people in the region as well as to determine the factors influencing wood harvesting in the region. Three hundred copies of structured questionnaire were used to elicit information from the respondents. Focused Group Discussion and Key Informant Interview were also used. Data were analyzed using descriptive statistics and logistic regression. Results show that various livelihood activities were engaged in by the respondents, prominent among which were food crop production, cash crop production, charcoal production, among others. Among the factors that were responsible for wood harvesting in the region, only age, occupation, household size and the distance of respondent's house to the forest were significant at $5 \%$. It was observed that excessive wood harvesting has negatively affected the forests in the study area as most of the forests have been greatly degraded. This study recommends that the activities of forest communities should be regulated by local authorities and governments, at different levels, in order to sustain the forests in the region.
\end{abstract}

Key words: timber, charcoal, lumbering, regression, fuelwood

\section{INTRODUCTION}

Wood harvesting refers to the removal of forest vegetation, like trees, shrubs for timber, fuelwood and charcoal production without intention of replacement (FAO, 2005). Livelihood refers to the activities undertaken by people and the assets owned by them that guarantee them decent living conditions (Ellis 2000; Aduse-Poku et al., 2003). The effects of wood harvesting on the livelihoods of forest and rural communities can be described as great, as most of the dwellers depend on the forests for their living. Therefore, the loss of the forests means the livelihood of the forest dwellers would be hard hit. Though wood harvesting which involves removal of forest wood for timber, charcoal or fuelwood may not lead to total forest clearance and may not necessarily constitute deforestation, such activities are crucial, despite that they may only affect a small proportion of trees per hectare, they can damage wide area of the forest and impact negatively on the livelihood of other people that depend on the forests for survival. Forests are particularly important among the rural poor who have access to few resources beyond the forest (Balogun et al., 2014). Most of the forest resources that communities live on are however becoming extinct or unavailable due to continuous and excessive exploitation without any attempt to re-grow them. According to Nzeh and Eboh (2007), poor people have been able to exploit the forest for food, fuelwood and other marketable products which create both income and employment for the rural dwellers.

Forests, particularly in the tropics, are being destroyed at an alarming rate in recent years especially in Nigeria and specifically in Ibarapa region of southwest, Nigeria. The rate of deforestation in Nigeria, resulting from wood harvesting and other human activities, appears to have accelerated in recent years (Nzeh and Eboh, 2008). The extent of forest loss resulting from wood harvesting in any particular location or region should therefore be viewed with economic, ecological and human consequences in mind. This is because forest loss and consequent degradation may in many ways be irreversible. In the short term, because of the extensive nature of forest, the impact of activities altering their condition is not immediately apparent and as a result they are largely ignored by those who cause them.

The degradation of the forest ecosystem has obvious ecological effects on the immediate environment, but it may also affect distant areas (Lescuyer et al., 2014). For instance, agricultural plains or valleys that depend upon forest highlands for their water may suffer from flooding or drought after destruction of the forests. Genetic damages and losses of plants, animals and insects can also be serious and possibly permanent (FAO, 2017). 
As environmental degradation and its impact come clearly into focus (Obalum et al., 2012), it can be deduced that the renewable forest resources may be exhausted and that man stands the risk of destroying his environment if all the impacts of deforestation emanating from wood harvesting and other anthropogenic activities are allowed to go on unchecked. In view of this, it is therefore, imperative to assess the effects of wood harvesting for various purposes on the livelihood of Ibarapa people of Southwest Nigeria as well as the resultant effect on the environment which is the major reservoirs of our natural resources and most especially the forestry resources.

In Nigeria, especially the south-western part, wood harvesting resulting in forest depletion and loss is an ongoing phenomenon. It is becoming more evident with increasing population of the region (NPC, 2006). The effects of such depletion have led to a decline in forest cover, forest degradation, impoverishment of the soil and general deterioration in environmental conditions (Aluko et al., 2020).

Therefore, to find out the economic implications and the effects of wood harvesting on the livelihood of rural communities, especially in Ibarapa land, southwest, Nigeria, there was need to carry out this study. This would enable forestry policy makers, other stakeholders and even farmers in the study area to be better informed about the implications of forest resources depletion and seek innovative means and ways to combat the menace of deforestation resulting from wood harvesting and other human activities.

Forest loss due to excessive and unregulated wood harvesting and other human activities is threatening rural and forest households' incomes and consumption of non-wood forest products (NWFPs). Considering the importance of forest and its resources both for present and future generations in both urban and rural communities in Nigeria and the region under study in particular, there was therefore the need to carry out adequate assessment of the effect of this dwindling natural resource in order to save the forest and minimize the resulting environmental degradation that occur due to forest degradation as a result of excessive and uncontrolled wood harvesting.

This study is also germane since there is dearth of information on the effects of wood harvesting on the livelihood of rural communities where the forests are located. In addition, several studies have been carried out on deforestation in the southwest, Nigeria, especially as they relate to forest reserves, but none of the studies has addressed the effects of wood harvesting on the means of living of rural communities especially as it relates to outside forest reserves (OFRs) or non-forest- reserve rural communities. This study therefore attempted to identify the sources of livelihood of the people; determine factors influencing wood harvesting and examine how wood harvesting has affected the livelihood of the people in the study area.

\section{MATERIALS AND METHODS \\ Study Area}

This study was conducted in Ibarapa area, Southwest of Nigeria. The Ibarapa people are a group of Yoruba people located in the south-western part of Nigeria (Abimbola, 2006). The name of the group is derived from a local cultivar of the melon plant, known locally as Egusi Ibara, which was historically acknowledged by neighbouring peoples such as the Egbas, Ibadans and Oyos to be extensively cultivated in the area. The Ibarapa area falls within latitudes $70.15^{\prime} \mathrm{N}$ and $70.55^{\prime} \mathrm{N}$ and longitudes $30.00 \mathrm{E}$ and $30.30^{\prime} \mathrm{E}$. It is located ca. $100 \mathrm{~km}$ north of the coast of Lagos, and about $95 \mathrm{~km}$ west of the Oyo state capital and neighbouring city of Ibadan. They border Yorubas of Onko extraction to the North (Iwajowas Kajola and Iseyin LGAs) and Yorubas of Oyo extraction to the East (Ibadan). The Yewas or Egbados to the West, and the Egbas to the South (Abimbola, 2006).

The area is ca. $2,496 \mathrm{~km}^{2}$ in geographical size, and consists mostly of rolling savannah with forests situated along the southern border and in isolated patches along river courses such as the Ogun. The natural vegetation was originally rainforest but that has been mostly transformed into derived type savannah as a result of several centuries of agricultural practices (Abimbola, 2006). Most of the land lies at elevations ranging between 120 and 200 $\mathrm{m}$ above sea level, but rocky inselbergs and outcrops can be seen rising to $340 \mathrm{~m}$ (ca. 1,115 ft) Ibarapa land is traditionally made up of 7 principal towns known as the Ibarapa-Meje (Ibarapa Seven), and their surrounding villages and farmsteads. These towns include Igangan, Eruwa, Aiyete, Tapa, Idere, Igbo-Ora, and Lanlate. Tapa and Aiyete are in located Ibarapa North Local Government Area (LGA); Igangan, Idere and Igbo-Ora located are in Ibarapa Central; while Lanlate and Eruwa are located in Ibarapa East LGA. The three local governments were created by the federal government of Nigeria authorities in 1996 when Ibarapa East was carved out from the old Ibarapa Local Government while Ibarapa Central and North were carved out of the former Ifeloju LGA.

\section{Data Collection and Sampling Procedure}

Data was collected through the use of questionnaire, focus group discussion and key informant interview methods. Discussions with groups of people was mainly at community level and such groups included farmers' groups $\backslash$ associations, women as well as youth groups who derived one form of benefit or the other from the forest. This approach would help to capture the collective perceptions, views and ideas from these groups about critical issues as they relate to wood harvesting and the effects on their livelihood. Structured questionnaire was administered through simple random technique to sampled households within the study area. 
Three hundred copies of the questionnaire were administered on randomly selected rural household heads in all the three LGAs that make up Ibarapa Land. One hundred copies of the questionnaire were administered in each of the three LGAs. However, only two hundred and 292 copies were found useable for this study. This is because eight copies of the questionnaire were discarded due to incomplete and mismatched information. At least a FGD and one Key Informant interview was conducted in each of the communities.

\section{Data Analysis}

Data were analysed using descriptive statistics such as frequency distribution, percentages, as well as inferential statistics such as Logistic Regression. The Logistic Regression is expressed as:

$$
\begin{aligned}
& \mathrm{LnY}=\mathrm{b}_{0}+\mathrm{b}_{1} \mathrm{X}_{1}+\mathrm{b}_{2} \mathrm{X}_{2}+\mathrm{b}_{3} \mathrm{X}_{3}+\mathrm{b}_{4} \mathrm{X}_{5}+ \\
& \mathrm{b}_{6} \mathrm{X}_{6}+\mathrm{b}_{7} \mathrm{X}_{7}+\mathrm{b}_{8} \mathrm{X}_{8}+\mathrm{e}_{\mathrm{i}}
\end{aligned}
$$

where $Y$ is harvesting of wood from the forest in the last one year ( 1 , if respondent has harvested wood from the forest in the last one year; 0 if otherwise), $X_{1}$ is gender of respondent, $X_{2}$ is age of respondent (in years), $X_{3}$ is educational qualification, $X_{4}$ is wood harvesting experience (in years), $X_{5}$ is household size, $X_{6}$ is distance of home to the forest (in $\mathrm{km}$ ), $X_{7}$ is land ownership, $X_{8}$ is occupation/livelihood activities, and $e_{i}$ is error term.

\section{RESULTS AND DISCUSSION}

Table 1 shows the socioeconomic characteristics of the respondents. The results showed that $4.79 \%$ of the respondents were less than 30 years, while $18.49 \%$ were between 30 and 40 years of age; those that were above 60 years accounted for $22.94 \%$. It therefore could be inferred that inhabitants of forest communities cuts across different age groups and most of the inhabitants were still within the working age group and this possibly explains the spate of wood harvesting in the region, since most of them were still agile and could easily move around. About $69 \%$ of the respondents were male while female accounted for about $31 \%$. In addition, about $62 \%$ of the respondents were Christians while about $38 \%$ practice Islamic religion. Thus most residents of the forest communities were Christians. Furthermore, from the educational distribution, about $38.36 \%$ of the respondents had primary education and $33.22 \%$ had secondary education while about $24 \%$ had no formal education. About $56 \%$ of the respondents were from homes with household size of 5-10. This therefore reveals that household sizes in the study area were large. Experiences in developing countries indicate that large household size is associated with poverty and poverty is a catalyst for environmental degradation in rural areas. This possibly explains why forests in the region have been significantly depleted and the environment degraded (Etong et al., 2016).
From Table 2, various options were given by the respondents as their perceived effect of wood harvesting on their livelihoods. About $18 \%$ of the respondents indicated that there was loss of farm crops and low farm yield from their farmland and this they claimed has significantly affected their livelihood. This is because wood harvesting for fuelwood, timber and charcoal, in some cases, causes destruction of farm crops and also exposes the soil to excessive heat from sunlight, leading to loss of soil nutrients. Nearly $14 \%$ of them pointed out that there was scarcity of fuelwood for domestic cooking while $14.19 \%$ stated that excessive wood harvesting in their locality has led to scarcity of wood for local wood industries that relied on wood for furniture making which serves as their source of income generation and livelihood. About fifteen percent of the respondents agreed that the scarcity of wood arising from excessive harvesting of wood has given rise to high cost of planks in their area.

Some of the key informants lamented that excessive wood harvesting has brought about deforestation in their localities and this has made their communities susceptible to erosions and floods. They stressed further that wood harvesting has also caused soil degradation which has brought about loss of soil fertility. In other words, wood harvesting results to deforestation which exposes the surface of fertile lands to the harsh conditions of the atmosphere like the radiation from the sun and the blowing away of the top soils by heavy winds, thereby leaving surfaces of lands hard and lacking in soil nutrients. This corroborates the work by Amisah et al. (2009) which affirms that many forest communities' farmlands are fragile and can be easily made less productive by small changes in their ecology.

Table 1: Socioeconomic characteristics of respondents

\begin{tabular}{llcc}
\hline Variable & & Frequency & Percentage \\
\hline Age & $<30$ years & 14 & 4.79 \\
& 30-40 years & 54 & 18.49 \\
& 41-50years & 85 & 29.10 \\
& 51-60years & 72 & 24.65 \\
& Above 60year & 67 & 22.94 \\
Gender & Total & 292 & 100 \\
& Male & 202 & 69.17 \\
Religion & Female & 90 & 30.82 \\
& Total & 292 & 100 \\
Marital & Christianity & 180 & 61.64 \\
Status & Islam & 112 & 38.36 \\
& Total & 292 & 100 \\
& Single & 12 & 4.11 \\
& Married & 252 & 86.30 \\
Educational & Divorced & 3 & 1.02 \\
Qualification & No formal education & 70 & 8.56 \\
& Primary education & 112 & 100 \\
& Secondary education & 97 & 23.97 \\
& Tertiary education & 13 & 38.36 \\
Household & Total & 292 & 4.45 \\
Size & Less than 5 & 34 & 100 \\
& 5-10 & 164 & 11.64 \\
& 11-15 & 58 & 56.16 \\
& Above 15 & 36 & 19.86 \\
& Total & 292 & 12.33 \\
& Sotal & 100 \\
\hline Source: Fis & &
\end{tabular}

Source: Field Survey, 2019 
Table 2: Forest communities perception of wood harvesting effect on their livelihood

\begin{tabular}{lcc}
\hline Perception & Frequency & Percentage \\
\hline Loss of farm crops/low farm yield & 56 & 18.06 \\
Scarcity of fuel wood for cooking & 43 & 13.87 \\
Loss of medicinal plants & 41 & 13.23 \\
Shortage of fodder for livestock & 34 & 10.97 \\
Scarcity of wood to local wood industries & 44 & 14.19 \\
High cost of planks & 45 & 14.52 \\
Depletion of wood stands in the community & 47 & 15.16 \\
Total & $310 *$ & 100 \\
\hline *Multiple Responses. Source: Field Survey, 2019 &
\end{tabular}

The informants further stressed that wood harvesting results in depletion of their forests and this causes disruption of normal weather patterns causing hot weather condition and leading to increasing drought that brings about crop failures.

From the focused group discussions, the forest fringe communities lamented that excessive wood harvesting from their forests has deprived them of forest resources such as wood products, food, medicinal plants and fodder for their livestock. This, according to them, has impacted negatively on their livelihood as it has resulted in lower agricultural productivity. This is in line with the study by Acheampong and Marfo (2011) which asserted that forest loss does not only reduce forest communities' contributions to national economic growth, but more critically, it threatens the livelihoods and traditions of rural and forest dwelling people. The people stressed that wood harvesting has brought about scarcity of fuelwood for household cooking, loss of medicinal plants as well as shortage of fodder for livestock. According to them, they therefore have to travel further distances into the forest to access products such as fuelwood, fodder and other forest products to enhance and sustain their livelihood and well-being.

When asked if their communities have benefitted from income generated from wood harvesting, some of the community leaders interviewed affirmed that they have not benefitted, notwithstanding the negative impacts such activities have had on their forests as well as on the collection of Non Timber Forest Products (NTFPs) in their communities. They further stressed that excessive and illegal tree felling in their communities, results in destruction of their farmland, crops and farming activities.

Table 3 shows that some of the livelihood activities engaged in by the respondents included food crop production, cash crop production, livestock keeping, lumbering/charcoal production, as $20.89 \%$ of them claimed food crop production is their main livelihood activity while $21.23 \%$ claimed lumbering and charcoal production were their main economic activities.
Table 4 shows the results of the regression analysis of the factors influencing wood harvesting among the forest communities in the study area. From the result, it was discovered that distance of home to the forest, type of livelihood activities (occupation) and household size were all positively significant at 5\% level, while age of the household head was negatively significant at $5 \%$. This implies that older people are less likely to harvest wood in the forests when compared to younger people. This may not be unconnected with the decline in strength and agility to move around the forest to harvest wood either for timber, charcoal or fuelwood. The type of livelihood activities or occupation of the people also played significant role in determining their harvesting of wood from the forests. The odds are that those who engaged in livelihood activities such as lumbering and charcoal production are more likely to harvest wood in the forests than others who engaged in other livelihood activities. Likewise, household size was statistically significant. This means that as the number of people in a particular household increases, the need to cater for the food and other requirements of the household may increase and this may require them to mount more pressure on the forests for fuelwood for household cooking or timber and charcoal for household income. This will in turn have serious implication on the future existence of the forests. This is in agreement with Kola-Oladiji et al. (2016) who asserted that rural household with larger household size tends to exert more pressure on the forest and its resources in other to cater for the household's needs.

Table 3: Main livelihood/economic activities of respondents

\begin{tabular}{lcc}
\hline Variable & Frequency & Percentage \\
\hline Food Crop Production & 61 & 20.89 \\
Cash Crop production & 38 & 13.01 \\
Livestock keeping & 37 & 12.67 \\
Wage employment & 36 & 12.33 \\
Artisanship & 25 & 8.56 \\
Trading & 33 & 11.30 \\
Lumbering & 30 & 10.27 \\
Charcoal Production & 32 & 10.96 \\
Total & 292 & 100 \\
\hline
\end{tabular}

Source: Field Survey, 2019

Table 4: Logistic regression result showing factors influencing wood harvesting among forest fringe communities in Ibarapa Area of Oyo State

\begin{tabular}{lccccc}
\hline Variable & $\mathrm{B}$ & S.E. & Wald & Sig. & Odd Ratio \\
\hline $\mathrm{X}_{1}(\mathrm{GDR})$ & 2.432 & 1.451 & 2.809 & 0.711 & 11.381 \\
$\mathrm{X}_{2}$ (AGE) & -0.222 & 0.134 & 2.882 & $0.032^{*}$ & 0.800 \\
$\mathrm{X}_{3}$ (EDUC) & 0.432 & 1.453 & 0.088 & 0.533 & 1.540 \\
$\mathrm{X}_{4}$ (OCCUP) & 2.140 & 1.424 & 2.259 & $0.024^{*}$ & 8.499 \\
$\mathrm{X}_{5}$ (WHE) & -0.342 & 0.127 & 1.901 & 0.442 & 0.710 \\
$\mathrm{X}_{6}$ (HHS) & 0.731 & 0.178 & 17.225 & $0.040^{*}$ & 2.077 \\
$\mathrm{X}_{7}(\mathrm{DHF})$ & 3.633 & 1.621 & 5.023 & $0.028^{*}$ & 37.826 \\
$\mathrm{X}_{8}(\mathrm{LO})$ & 3.311 & 1.467 & 4.350 & 0.225 & 27.412
\end{tabular}

GDR - Gender, AGE - Age, EDUC - Educational level,

OCCUP - Occupation, WHE - Wood harvesting experience,

HHS - Household size, DHF - Distance of home to forest,

LO -Land ownership; *Significant at $5 \%$ 
Likewise, the nearness of respondents' houses to the forest plays a key role in wood harvesting from the forest by the rural people. The odds are that respondents whose houses were near to the forest were likely to harvest wood from the forest more than those whose houses were far away from the forest. Therefore, proximity to the forest is a significant determinant of people's involvement in wood harvesting within the forest. This corroborates the study by Kola-Oladiji et al. (2016) that nearness to forest reserves is a significant determinant of their exploitation by forest fringe communities.

\section{CONCLUSION AND \\ RECOMMENDATIONS}

This study examined the effects of wood harvesting on the livelihood of forest communities in Ibarapa region in southwest of Nigeria. It also assessed factors that influenced wood harvesting in the region. From the study, it was discovered that various economic activities were embarked upon in the region. Results of the logistic regression showed that age, occupation, household size and distance of house of respondents to the forests were significant, at $5 \%$, among the factors that influence the people to harvest wood in the forests in the region. It was also observed from the study that the forests in the region have been significantly depleted and degraded as a result of unregulated wood harvesting in the region. This will also significantly affect the livelihood of the people as the land would no longer be fertile enough to produce good crop yields from their farming activities. Likewise, excessive logging and cutting of trees for fuel wood, without planting trees in replacement, would also affect sustainable management of the forest because the activities of the present generation would affect the ability of future generation to meet their needs.

It is therefore recommended that activities of the forest communities should be regulated by governments, both at the local, regional and national levels. In addition, the people should be enlightened and sensitized on the need for tree planting and the associated benefits. Policies favourable to adequate financing of the forestry sector should be made and implemented by the Nigerian governments at the federal, state and local government levels, so as to increase timber production, for sustainable human use. A robust mechanism should also be put in place to ensure that the remaining natural forest resources are conserved and sustainably managed.

\section{REFERENCES}

Abimbola K. (2006). Yoruba Culture: A Philosophical Account. Iroko Academic. (p. 40). ISBN 978-1-9053880-04
Acheampong E. and Marfo E. (2011). The impact of tree tenure and access on chainsaw milling in Ghana. Ghana J. Forestry, 27, 68-86

Aduse-Poku K., Nyinaku F., Yao A.V., et al. (2003). Improving rural livelihoods within the context of sustainable development: case study of Goaso Forest District. A Report of Project organized and financed by Tropenbos International Ghana (TBI-Ghana) and University of Amsterdam, Netherlands

Aluko O.J., Adejumo A.A. and Bobadoye A.O. (2020). Adaptive strategies to deforestation among nontimber forest products (NTFPS) collectors across gender line in Oluwa Forest Reserve area of Ondo State, Nigeria. Agro-Science, 19 (2), 48-52

Amisah S. Gyampoh A.B., Sarfo-Mensah P. and Quagrainie K.K. (2009). Livelihood trends in response to climate change in forest fringe communities of the Offin Basin in Ghana. Appl. Sci. Environ. Manage., 13, 5-15

Balogun O.L., Yusuf S.A., Osalusi C.S., Olowe O.O. and AyoBello T.A. (2014). Determinants of market participation in non-timber forest products among households of rain forest in Ondo State, Nigeria. $J$. Forestry Social Sci., 12 (2), 18-33

Ellis F. (2000). Rural Livelihoods and Diversity in Developing Countries. Oxford: Oxford University Press, 273 pp.

Etong D., Djentontin I.N.S. and Kanninen M. (2016). Poverty and environmental degradation in Southern Burkina Faso: An assessment based on participatory methods. Land, 5 (20), 1-23

FAO (2017). Supporting the energy needs of refugees and host communities: the role of forests [video]. Accessed 1 Dec. 2017 from: https://www.youtube.com/ watch? $\mathrm{v}=\mathrm{ysI} 0 \mathrm{C} 6 \mathrm{vO} 4 \mathrm{~A} 4$ \& feature $=$ youtu.be

Food and Agricultural Organization. (2005). Mobilizing resources to halve world hunger. Paper Prepared for the 2005 World Summit, Rome

Kola-Oladiji K.I., Adepoju A.O. and Awe F. (2016). Socio-economic assessment of the activities of fringe communities on Sakpoba Forest Reserves: implication for sustainable livelihood and forest management. $J$. Sustainable Environ. Manage., 8, 74-87

Lescuyer G., Cerutti P.O., Tshimpanga, P., et al. (2014). The domestic market for small-scale chainsaw milling in the Democratic Republic of Congo: present situation, opportunities and challenges. Occasional Paper 112. CIFOR, Bogor, Indonesia

National Population Commission (NPC) (2006). Nigerian Population Census Report, 2006, Abuja, Nigeria

Nzeh C.E.P. and Eboh E.C. (2007). Analysis of income effects of forest products activities among rural households in Enugu State Nigeria. J. Agric. Soc. Res. (JASR), 7 (1), 23-33

Nzeh C.E.P. and Eboh E.C. (2008). Socio-economic analysis of income effects of Forest products activities among rural households in Enugu State, Nigeria. Agro-Science, 7 (1), 22-26

Obalum S.E., Buri M.M., Nwite J.C., et al. (2012). Soil degradation-induced decline in productivity of subSaharan African soils: the prospects of looking downwards the lowlands with the sawah ecotechnology. Appl. Environ. Soil Sci., Vol. 2012, Article ID 673926, 10 pp. DOI: 10.1155/2012/673926 